\title{
KEWENANGAN PEMERINTAH DAERAH DALAM PENGATURAN LARANGAN PENAHANAN ATAU PENYIMPANAN DOKUMEN ASLI PEKERJA OLEH PENGUSAHA
}

\author{
Sinda Eria Ayuni, Sudarsono,Tunggul Anshari \\ Magister Ilmu Hukum, Program Pasca Sarjana Universitas Brawijaya \\ Jl. MT. Haryono No. 169 Malang, Jawa Timur, Indonesia \\ E-mail : sindaayuni@gmail.com
}

\begin{abstract}
The prohibition or recommendation for the detention of workers 'original documents is not clearly stipulated in the labor law so that some employers detain or retain workers' original documents to be made to bind workers. This is permissible if it becomes an agreement between workers and employers, but of course there will be some risks borne by workers if the original documents are guaranteed. In this case a clear and definite rule is needed regarding the prohibition of hold or save of original documents of workers by employers as an effort to protect workers. The government has the authority to make regulations that can protect workers from arbitrary rules made by employers
\end{abstract}

Keywords : Prohibition, Hold or Save, Original Documents, Workers, Employers

\begin{abstract}
Abstrak
Larangan atau anjuran penahanan dokumen asli pekerja oleh pengusaha tidak diatur secara jelas dalam undang-undang ketenagakerjaan sehingga beberapa pengusaha melakukan penahanan atau penyimpanan dokumen asli pekerja dijadikan sebagai jaminan untuk mengikat pekerja. Hal tersebut diperbolehkan jika menjadi kesepakatan antara pekerja dan pengusaha, namun tentu akan ada beberapa resiko yang ditanggung oleh pekerja apabila dokumen asli dijadikan jaminan. Dalam hal ini diperlukan suatu aturan yang jelas dan pasti tentang larangan penahanan atau penyimpanan dokumen asli pekerja oleh pengusaha sebagai upaya perlindungan terhadap pekerja. Pemerintah memiliki kewenangan untuk membuat peraturan yang dapat melindungi pekerja dari kesewenang-wenangan aturan yang dibuat oleh pengusaha.

Kata Kunci : Larangan, Penahanan atau Penyimpanan, Dokumen Asli, Pekerja, Pengusaha
\end{abstract}

\section{A. PENDAhuluan}


Perusahaan memiliki peran penting dalam pembangunan ekonomi dan penciptaan lapangan kerja, sehingga kebijakan dalam dunai kerja harus didukung oleh pemerintah serta lembaga-lembaga terkait lainnya salah satunya dengan mengeluarkan undang-undang, keputusan, dan regulasi-regulasi lainnya untuk mengatur ketenagakerjaan di Indonesia. Seluruh tenaga kerja dan pihak-pihak yang menggunakan tenaga kerja wajib mematuhi peraturan-peraturan ini. Peraturan-peraturan ini mencakup banyak hal seperti perlindungan hukum pekerja, kewajiban pengusaha atau perusahaan, hak yang didapat oleh pekerja, dan lain sebagainya. Pemerintah juga memiliki peran pengawasan dalam pelaksanaan aturan ketenagakerjaan supaya tidak terdapat pelanggaran terhadap peraturan tersebut.

Indonesia dibagi atas daerah-daerah Provinsi dan daerah Provinsi dibagi atas Kabupaten dan Kota yang tiap Provinsi, Kabupaten dan Kota mempunyai Pemerintahan Daerah diatur dalam undang-undang, hal tersebut merupakan amanat yang terkandung dalam UndangUndang Dasar Negara Republik Indonesia Tahun 1945 (UUD NRI Tahun 1945). ${ }^{1}$ Penyelenggaraan Pemerintah Daerah Provinsi, Kabupaten maupun Kota, pemerintah harus mempunyai cerminan dari pemerintahan yang sesuai dengan Negara Kesatuan Republik Indonesia dengan menjalankan asas desentralisasi.

Desentralisasi merupakan pelimpahan kekuasaan dan kewenangan dari pusat ke daerah dimana kewenangan tersebut bersifat otonom yang dilaksanakan oleh pemerintahan daerah tanpa ada intervensi dari pusat. $^{2}$ Penyelenggaraan desentralisasi pemerintah diberikan kewenangan untuk mengatur dan mengurus sendiri pemerintahan dalam bentuk otonomi daerah. Dalam Pasal 1 Angka 6 Undang-Undang Nomor 23 Tahun 2014 tentang Pemerintahan Daerah yang menyatakan bahwa otonomi daerah merupakan hak, wewenang dan kewajiban daerah otonom untuk mengatur dan mengurus sendiri urusan pemerintahan dan kepentingan masyarakat setempat dalam sistem Negara Kesatuan Republik Indonesia. Dari ketetntuan tersebut maka pemerintah daerah dalam ruang lingkupnya berhak untuk menjalankan otonomi seluas-luasnya.

Peraturan daerah merupakan peraturan yang berkedudukan sebagai produk hukum paling rendah oleh karena itu dalam pembentukan peraturan daerah harus memperhatikan tiga materi muatan yakni seluruh materi muatan dalam peraturan daeah harus mencerminkan kebutuhan penyelenggaraan otonomi daerah dan tugas pembantuan, pembentukan peraturan daerah tidak boleh bertentangan dengan peraturan-peraturan yang lebih tinggi yang menjadi sumber atributif kewenangannya, dan muatan peraturan daerah merupakan derivasi atau penjabaran lebih lanjut dari peraturan yang lebih tinggi. ${ }^{3}$

Undang-Undang Nomor 13 Tahun 2003 tentang Ketenagakerjaan (Selanjutnya disebut UU Ketenagakerjaan) merupakan payung hukum ketenagakerjaan karena Undang-Undang

\footnotetext{
${ }^{1}$ Lihat Pasal 18 Undang-Undang Dasar Negara Republik Indonesia Tahun 1945

2 Jazim Hamidi, Optik Hukum Peraturan Daerah Bermasalah, (Malang: Prestasi Pustaka Publisher, 2011), hlm 18

${ }^{3}$ Lihat Pasal 236 Undang-Undang Nomor 23 Tahun 2014 tentang Pemerintahan Daerah
} 
tersebut mengatur dan berkaitan dengan sebelum masa kerja, pada masa kerja dan sesudah masa kerja. Namun, terdapat suatu hal yang tidak diatur dalam undang-undang tersebut yaitu mengenai larangan ataupun anjuran penahanan atau penyimpanan dokumen asli pekerja yang dilakukan oleh pengusaha sehingga tidak ada kepastian hukum apabila terdapat pengusaha yang melakukan tindakan tersebut.

Penahanan atau penyimpanan dokumen asli milik pekerja dijadikan sebagai jaminan pengusaha atau pemberi kerja yang bertujuan untuk memberikan rasa percaya terhadap pekerja dan membuat pekerja terikat dengan aturan perusahaan. Dokumen asli milik pekerja yang ditahan atau disimpan salah satunya adalah ijazah, sebagai benda yang didalamnya melekat hak milik bagi seseorang yang menjadi bukti bahwa orang tersebut telah menempuh pendidikan. Ketika seseorang melamar pekerjaan di perusahaan maka akan diminta ijazah terakhir sebagai syarat kerja, yang seharusnya cukup dengan melampirkan fotocopy ijazah yang telah dilegalisasi sebagai bukti bahwa ijazah tersebut sama dengan aslinya. Sehingga ijazah asli tidak perlu ditahan atau disimpan oleh perusahaan sebagai jaminan. Ketika perusahaan menahan atau menyimpan dokumen asli pekerja jika terjadi kerusakan, atau hilang dan mungkin terjadi suatu hal yang tidak diinginkan seperti kebakaran pada tempat penyimpanan dokumen atau perusahaan itu sendiri tentu dapat merugikan pemilik dokumen tersebut sebab tidak ada kepastian hukum untuk memberi perlindungan dokumen asli milik pekerja dalam UU No. 13 Tahun 2003 tentang Ketenagakerjaan.

Pengaturan penahanan atau penyimpanan dokumen asli pekerja oleh pengusaha hanya terdapat dalam Pasal 42 Peraturan Daerah Provinsi Jawa Timur Nomor 8 Tahun 2016 tentang Penyelenggaraan Ketenagakerjaan yang berbunyi "Pengusaha dilarang menahan atau menyimpan dokumen asli yang sifatnya melekat pada pekerja sebagai jaminan."4 Dokumen asli yang dimaksud adalah Kartu Tanda Penduduk (KTP), Surat Izin Mengemudi (SIM), akte kelahiran, kartu keluarga, paspor, ijazah dan sertifikat. ${ }^{5}$ Berkaitan dengan larangan penahanan atau penyimpanan dokumen asli pekerja jika melihat hierarki perundang-undangan pada Pasal 7 ayat (1) UU No. 12 Tahun 2011 tentang Pembentukan Peraturan Perundang-undangan, Peraturan Daerah Provinsi terletak pada urutan nomor dua dari bawah, satu tingkat di atas Peraturan Daerah Kabupaten/Kota. Seacara hierarki perundang-undangan Peraturan Daerah merupakan peraturan pelaksana dari perundang-undangan di atasnya dan ruang lingkup Peraturan Daerah Provinsi terbatas pada wilayah tertentu. Sehingga dalam hal ini diperlukan penjelasan terkait ketepatan pengaturan larangan ataupun anjuran penahanan atau penyimpanan dokumen asli pekerja oleh pengusaha dalam suatu undang-undang.

Melihat fenomena hukum yang terjadi bahwa UU Ketenagakerjaan tidak mengatur secara jelas tentang larangan atau anjuran penahanan atau penyimpanan dokumen asli pekerja oleh pengusaha sedangkan Peraturan Daerah Provinsi Jawa Timur Nomor 8 Tahun 2016

\footnotetext{
${ }^{4}$ Lihat Pasal 42 Peraturan Daerah Provinsi Jawa Timur Nomor 8 Tahun 2016 tentang Penyelenggaraan Ketenagakerjaan

${ }^{5}$ Lihat Lampiran Pasal 42 Peraturan Daerah Provinsi Jawa Timur Nomor 8 Tahun 2016 tentang Penyelenggaraan Ketenagakerjaan
} 
tentang Penyelenggaraan Ketenagakerjaan mengatur larangan penahanan atau penyimpanan dokumen asli yang sifatnya melekat pada pekerja sebagai jaminan pengusaha. Dari hal ini muncul ketidakpastian hukum karena dalam UU Ketenagakerjaan tidak mengatur secara jelas mengenai larangan atau anjuran penahanan dokumen asli pekerja sedangkan dalam Peraturan Daerah Provinsi Jawa Timur Nomor 8 Tahun 2016 tentang Penyelenggaraan Ketengakerjaan Mengatur hal tersebut sehingga aturan itu hanya dapat diimplementasikan khusus di Jawa Timur, sedangkan permasalahan penahanan dokumen asli pekerja tidak hanya terjadi di Jawa Timur. Maka dalam hal ini, penulis menganalisis kewenangan pemerintah daerah provinsi untuk mengatur larangan penahanan dokumen asli pekerja oleh pengusaha berdasarkan dari ratio legis Pasal 42 Peraturan Daerah Provinsi Jawa Timur Nomor 8 Tahun 2016 tentang Penyelenggaraan Ketenagakerjaan.

Peraturan lebih rendah seharusnya memiliki landasan dasar dalam pembentukkan perundang-undangan, menurut Hans Kelsen dalam teori The Pure Theory of Law hukum itu dinyatakan sah apabila dibuat oleh lembaga yang berwenang membentuknya dan berdasarkan norma yang lebih tinggi maka norma lebih rendah dibentuk oleh norma yang lebih tinggi (lex superiori derogate legi inferiori) dan hukum berebentuk jenjang-jenjang dan berlapis-lapis membentuk hierarki, dimana suatu norma yang lebih rendah berlaku, bersumber dan berdasar pada norma yang lebih tinggi. ${ }^{6}$ Seharusnya muatan Pasal 42 Peraturan Daerah Provinsi Jawa Timur Nomor 8 Tahun 2016 tentang Penyelenggaraan Ketengakerjaan bersumber maupun berdasarkan pada Undang-Undang diatasnya karena peraturan lebih rendah tidak boleh mengatur sendiri apa yang ingin diatur karena materi muatan peraturan daerah yang lebih rendah merupakan penjabaran lebih lanjut dari peraturan yang lebih tinggi.

\section{B. RUMUSAN PERMASALAHAN}

Berdasarkan latar belakang yang telah diuraikan dapat ditarik suatu rumusan masalah yaitu apa ratio legis dan dasar hukum Pasal 42 Peraturan Daerah Jawa Timur No. 8 Tahun 2016 tentang Penyelenggaraan Ketenagakerjaan mengatur larangan penahanan atau penyimpanan dokumen asli pekerja oleh pengusaha.

\section{METODE PENELITIAN}

Jenis penelitian yang digunakan ialah yuridis normatif dimaknai dengan suatu prosedur ilmiah untuk menemukan kebenaran berdasarkan logika keilmuan hukum dari sisi normanya. Penelitian ini difokuskan untuk mengkaji kaidah atau norma pada hukum positif. ${ }^{7}$ Pendekatan yang digunakan dalam penelitian ini adalah pendekatan perundang-undangan (statute

\footnotetext{
${ }^{6}$ Ni'matul huda, Pengawasan Pusat terhadap Daerah dalam Penyelenggaraan Daerah, (Yogyakarta: FH UII Press, 2007), hlm 97-98

${ }^{7}$ Johny Ibrahim. Teori dan Metodologi Penelitian Hukum Normatif, (Malang: Bayumedia, 2011). Hlm. 295.
} 
approach); dan pendekatan konseptual (conceptual approach). Bahan hukum dari penelitian ini terdiri dari bahan hukum primer, bahan hukum sekunder dan bahan hukum tersier. Teknik Pengumpulan Bahan Hukum dalam penelitian ini adalah dengan melakukan studi dokumen, studi kepustakaan (library research) dan studi internet, yang dimaksud adalah pengkajian informasi tertulis mengenai hukum yang berasal dari berbagai sumber. Teknik pengumpulan bahan hukum dalam penelitian ini adalah dengan penelusuran kepustakaan dan akses internet. Teknik analisis yang digunakan ialah interprestasi gramatikal dan interprestasi sistematis. Serta dibutuhkan suatu metode analisis data deskriptif analitis yang mengacu pada suatu masalah tertentu yang kemudian dikaitkan dengan pendapat pakar hukum maupun berdasarkan peraturan perundang-undangan yang berlaku. ${ }^{8}$ Pada penelitian hukum normatif, pengolahan data hakikatnya kegiatan untuk mengadakan sistematisasi terhadap bahan-bahan hukum tertulis. Sistematisasi berarti membuat klasifikasi terhadap bahan-bahan hukum tertulis tersebut untuk memudahkan pekerjaan analisis.

\section{PEMBAHASAN}

\section{Ratio Legis dan Dasar Hukum Pasal 42 Peraturan Daerah Provinsi Jawa Timur No. 8 Tahun 2016 Tentang Penyelenggaraan Ketenagakerjaan}

Ratio legis merupakan suatu upaya yang digunakan untuk mencari sebab lahirnya suatu peraturan hukum. Satjipto Rahardjo berpendapat asas hukum merupakan sebab atau alasan bagi lahirnya peraturan hukum atau ratio legis peraturan hukum. ${ }^{9}$ Asas tidak akan habis melahirkan suatu peraturan hukum. Apabila terjadi suatu problematika dalam suatu peraturan maka harus dikembalikan kepada asas hukumnya untuk mencari penyelesaian. Hal ini sejalan dengan pernyataan Satjipto bahwa asas merupakan landasan yang paling luas bagi lahirnya suatu peraturan hukum, sebab sebelum menjadi norma atau peraturan hukum, hukum itu berbentuk sebuah asas yang mana asas dijadikan pengukur atau pondasi bagi berdirinya sebuah peraturan. Ketika mencari ratio legis pembentukkan peraturan hukum dalam suatu daerah, maka asas hukum dapat digunakan dan dilihat dari pembuatan/perancangan serta penyusunan peraturan tersebut.

Pada lampiran penjelasan Undang-Undang Nomor 12 Tahun 2011 tentang Pembentukan Peraturan Perundang-undangan dijelaskan untuk mengetahui kondisi hukum atau peraturan perundang-undangan yang mengatur mengenai substansi atau materi dalam peraturan perundang-undangan dalam hal ini peraturan daerah dapat dilihat dari bahan penyusunannya yaitu dasar pertimbangan filosofis, sosiologi dan yuridis. ${ }^{10}$ Selain ketiga aspek dasar pertimbangan filosofis, sosiologi dan yuridis itu dapat digunakan untuk

\footnotetext{
${ }^{8}$ Soerjono Soekanto dan Sri Mamudji, Penelitian Hukum Normatif suatu Tinjauan Singkat, (Rajawali Press, Jakarta, 1990) hlm 29.

${ }^{9}$ Satjipto Rahardjo, Ilmu Hukum, (Bandung: PT. Citra Aditya Bakti, 2005). Hlm 45

10 Penjelasan lampiran Undang-Undang Nomor 12 Tahun 2011 tentang Pembentukan Peraturan Perundang-undangan
} 
memahami penyusunan pedoman kebijakan teknis dan petunjuk pelaksanaan pengharmonisasian, pembulatan serta pemantapan konsepsi rancangan peraturan perundang-undangan sebagai standar konsepsi, prosedur dan teknik penyusunan serta perancangan peraturan perundang-undangan yang baik.

Sebagai upaya mencari jawaban lahirnya suatu peraturan hukum dalam Pasal 42 Peraturan Daerah Nomor 8 Tahun 2016 tentang Penyelenggarraan Ketenagakerjaan tentang larangan penahanan atau penyimpanan dokumen asli pekerja oleh pengusaha akan dianalisis dalam bab ini untuk mengetahui alasan dan tujuan mengapa aturan tersebut dibuat. Hal itu dapat dilihat dari pokok-pokok pikiran yang terdapat dalam konsideran suatu perundang-undang, penjelasan pasal, maupun landasan yuridis dan ladasan sosiologis. Landasan filosofis, landasan yuridis dan landasan sosiologis dari peraturan daerah provinsi dapat dilihat dari naskah akademik rancangan peraturan daerah provinsi. Pengaturan mengenai larangan penahanan atau penyimpanan dokumen asli pekerja oleh pengusaha pada Pasal 42 Peraturan Daerah Provinsi Jawa Timur Nomor 8 Tahun 2016 tentang Penyelenggaraan Ketenagakerjaan, penulis tidak menemukan adanya alasan yang secara jelas menyatakan alasan mengapa aturan larangan menahan atau menyimpan dokumen asli pekerja oleh pengusaha itu ada, baik secara yuridis, filosofis dan sosiologis dari naskah akademik rancangan peraturan daerah Provinsi Jawa Timur Nomor 8 Tahun 2016 tentang Penyelenggaraan Ketenagakerjaan.

Naskah akademik Peraturan Daerah Provinsi Jawa Timur Nomor 8 Tahun 2016 tentang Penyelenggaraan Ketenagakerjaan pada landasan filosofisnya seharusnya berdasarkan pandangan hidup, kesadaran dan cita hukum yang meliputi suasana kebatinan serta falsafah bangsa Indonesia yang bersumber dari Pancasila dan Undang-Undang Dasar Negara Republik Indonesia Tahun 1945. Pemerintah Daerah Provinsi Jawa Timur menganggap perlindungan hukum bagi pekerja berfungsi sebagai alat social control (berupa norma/pengaturan) dengan tujuan adanya peraturan daerah tentang penyelenggaraan ketenagakerjaan supaya dapat melindungi hak-hak pekerja. Mengingat pemerintah daerah mempunyai wewenang menetapkan peraturan daerah sesuai dengan Pasal 18 Undang-Undang Dasar Negara Republik Indonesia Tahun 1945 bahwa "Pemerintah Daerah berhak menetapkan peraturan daerah dan peraturan lain untuk melaksanakan otonomi dan tugas pembantuan". Maka pemerintah daerah mempunyai kewenangan untuk mengatur akan tetapi mengenai pengaturan larangan penahanan atau penyimpanan dokumen asli pekerja oleh pengusaha jika dilihat dari peraturan terkait seperti Undang-Undang Ketenagakerjaan, Peraturan Pemerintah ataupun Peraturan Presiden tidak mengatur secara jelas tentang larangan atau anjuran penahanan dokumen asli pekerja oleh pengusaha.

Adapun dasar pertimbangan sosiologis yang dimuat dalam naskah akademik adalah dikarenakan terdapat beberapa permasalahan tentang ketenagakerjaan di Jawa Timur antara lain: 
a. Jumlah angkatan kerja yang besar.

b. Kualitas tenaga kerja relatif rendah.

c. Kesempatan kerja masih terbatas, kesejahteraan buruh, posisi tawar yang sangat rendah akibat tingginya angka pengangguran, bahkan bagi buruh yang sudah bekerja pun menghadapi berbagai permasalahan seperti upah (kesejahteraan), eksploitasi atau penindasan yang dilakukan oleh pemilik modal, pembatasan hak buruh untuk berpartisipasi secara politis, melakukan demonstrasi dan permasalahan lain seperti buruh outsourcing, dan buruh kontrak. Banyaknya tenaga kerja yang berstatus outsourcing juga menjadi persoalan yang sangat rumit. Selain karena tidak ada kepastian dan keberlanjutan pekerjaannya, buruh/ Pekerja outsourcing di Indonesia diyakini sangat jauh dari sejahtera.

d. Rendahnya upah buruh/pekerja.

e. Perlindungan tenaga kerja yang dimaksudkan agar tenaga kerja dapat bekerja lebih produktif, sehat dan sejatera, sehingga mereka dapat hidup layak bersama keluarganya. Tenaga kerja atau buruh/pekerja sering merasa dirugikan atupun dieksploitasi oleh para pengusaha yang semena-mena mentapkan kebijakan bagi para karyawan maupun para buruh, minimnya upah dan jaminan akan keselamatan kerja merupakan bagian masalah ketenagakerjaan.

Selanjutnya, terdapat pertimbangan yuridis yang berguna untuk mengatasi permasalahan hukum dengan mempertimbangkan aturan yang telah ada, yang akan diubah atau yang akan dicabut guna menjamin kepastian hukum dan rasa keadilan dalam masyarakat. Pembentukkan Peraturan Daerah Provinsi Jawa Timur Nomor 8 Tahun 2016 tentang Penyelenggaraan Ketenagakerjaa secara yuridis memberikan bertujuan untuk memberikan penguatan dan perlindungan terhadap tenaga kerja lokal agar mampu bersaing dengan masuknya tenaga kerja asing di Jawa Timur. Sehingga dalam hal ini penulis tidak menemukan alasan yang jelas mengapa aturan larangan penahanan atau penyimpanan dokumen asli milik pekerja oleh pengusaha itu dibentuk.

Selain pada naskah akademik, penulis mencari alasan pengaturan mengenai larangan penahanan atau penyimpanan dokumen asli pekerja oleh pengusaha yang tercantum pada Pasal 42 Peraturan Daerah Provinsi Jawa Timur Nomor 8 Tahun 2016 tentang Penyelenggaraan Ketenagakerjaan dalam pokok-pokok pikiran pada konsideran serta penjelasan pasal, namun penulis tidak mendapatakan alasan yang jelas mengenai mengapa aturan itu dibuat, penjelasan pasal 42 hanya menyatakan "Dokumen asli yang dimaksud adalah Kartu Tanda Penduduk (KTP), Surat Izin Mengemudi (SIM), akte kelahiran, kartu keluarga, paspor, ijazah dan sertifikat".

Meskipun tidak terdapat alasan yang jelas tentang larangan penahanan atau penyimpanan dokumen asli milik pekerja oleh pengusaha dalam naskah akademik. Penulis menarik kesimpulan bahwa larangan penahanan atau penyimpanan dokumen asli milik pekerja oleh pengusaha merupakan upaya pemerintah untuk melindungi tenaga kerja 
dari permasalahan ketenagakerjaan di Jawa Timur sebagaimana di uraikan dalam landasan filosofis, dan landasan sosiologis diatas, yaitu :

a. Tenaga kerja sering merasa dirugikan atupun dieksploitasi oleh pemimpin atau para pengusaha yang semena-mena menetapkan kebijakan bagi para karyawan maupun para buruh.

b. Perlindungan tenaga kerja dibutuhkan karena tenaga kerja atau buruh/pekerja sering merasa dirugikan atupun dieksploitasi oleh para pengusaha yang semenamena mentapkan kebijakan bagi para karyawan maupun para buruh.

Dari pernyataan tersebut penulis berpendapat bahwa hal merugikan dan tindakan eksploitasi yang dilakukan oleh pengusaha kepada pekerja merupakan beberapa permasalahan tentang ketenagakerjaan di Jawa Timur hal itu dapat dibuktikan dengan latar belakang masalah yang terdapat dalam daftar invertaris permasalahan tenaga kerja di Jawa Timur, salah satunya ialah bahwa buruh tidak memiliki daya tawar yang kuat disertai dengan perjanjian kerja yang tidak transparan sehingga pemerintah beranggapan beberapa permasalahan terjadi akibat dari perjanjian kerja tersebut untuk itu pemerintah memberikan solusi dengan perlunya dibentuk suatu regulasi yang jelas tentang perjanjian kerja yang bersifat win-win solution.

Bentuk perjanjian kerja yang membuat posisi tawar pekerja tidak kuat adalah penahanan atau penyimpanan dokumen asli milik pekerja oleh pengusaha. Hal tersebut tentu sangat merugikan pekerja apabila dokumen asli yang dijadikan sebagai jaminan pengusaha hilang atau mengalami kerusakan karena kelalaian pengusaha, Sebagaimana kejadian yang telah dialami oleh 6 (enam) pekerja di daerah Kabupaten Sidoarjo, Jawa Timur pada tahun $2014^{11}$ mereka telah kehilangan ijazah asli mereka akibat kelalaian pengusaha, sehingga para penggugat beranggapan mereka telah mengalami suatu kerugian akibat ditahannya ijazah mereka, yang dimaksud rugi dalam hal ini yaitu kerugian karena kerusakan/kehilangan barang dan/atau harta kepunyaan salah satu pihak yang diakibatkan oleh kelalaian pihak lainnya. ${ }^{12}$

Berdasarkan Kamus Besar Bahasa Indonesia (KBBI) rugi adalah tidak mendapat faedah (manfaat), tidak memperoleh sesuatu yang berguna, dan dapat juga diartikan sebagai sesuatu yang kurang baik (tidak menguntungkan). Sedangkan merugikan adalah menyebabkan atau mendatangkan rugi bagi seseorang, dan dapat diartikan pula sebagai hal yang mendatangkan sesuatu yang kurang baik (seperti kerusakan, kesusahan) kepada seseorang.

Perlindungan merupakan hak yang diterima oleh tenaga kerja dan kewajiban bagi pengusaha dan pemerintah. Dalam Kamus Besar Bahasa Indonesia (KBBI), perlindungan di definisikan sebagai tempat berlindung dan/atau hal atau perbuatan melindungi.

${ }^{11}$ Catur Kiki Agustina, Achmad Wafik, Ritma Ratmi, M. Yazid, Sigit Arya Permadi, Moch. Noer Yahya, Dalam Putusan Mahkamah Agung Nomor: 186/Pdt. G/2014/PN. Sda

${ }^{12}$ Suharnoko, Hukum Perjanjian Teori Dan Analisis Kasus (Jakarta: Kencana: 2004), hlm. 115. 
Sedangkan pengertian perlindungan hukum adalah suatu upaya perlindungan yang diberikan kepada subyek hukum, tentang apa-apa yang dapat dilakukannya untuk mempertahankan atau melindungi kepentingan dan hak subyek hukum tersebut. ${ }^{13}$ Jadi perlindungan hukum menurut penulis adalah kegiatan yang dapat memberikan perlindungan terhadap pemenuhan hak dan kepastian hukum kepada para pihak.

Perlindungan merupakan hak dasar dan hak utama yang memang harus dipenuhi oleh pemberi kerja dan pemerintah. Sehingga dibuatlah aturan yang dapat melindungi pekerja dari hal yang dapat merugikan diri pekerja. Mengenai larangan penahanan atau penyimpanan dokumen asli pekerja oleh pengusaha dalam Pasal 42 Peraturan Daerah Provinsi Jawa Timur Nomor 8 Tahun 2016 tentang Penyelenggaraan Ketenagakerjaan diatur dalam Bab VIII tentang Hubungan Kerja, dalam Pasal 1 angka 29 Peraturan Daerah Provinsi Jawa Timur Nomor 8 Tahun 2016 tentang Penyelenggaraan Ketenagakerjaan tersebut hubungan kerja di definisikan sebagai hubungan antara pengusaha dengan pekerja/buruh berdasarkan perjanjian kerja, yang mempunyai unsur pekerjaan, upah dan perintah.

Tenaga kerja dan pemberi kerja memiliki suatu hubungan timbal balik yang tidak dapat dipisahkan. Hubungan tersebut dapat dikatakan sebagai hubungan interdependensi yang akan terjadi bila ada kedua belah pihak. Tenaga kerja membutuhkan pekerjaan dari pemberi kerja dan pemberi kerja juga membutuhkan tenaga kerja untuk melakukan kegiatan produksi untuk menghasilkan barang maupun jasa. Maka, hubungan yang demikian dapat disebut sebagai hubungan kerja dan hubungan industrial. Sebagaimana dalam UU No.13 Tahun 2003 tentang Ketenagakerjaan mendefinisikan hubungan kerja sebagai hubungan antara pengusaha dengan pekerja/buruh berdasarkan perjanjian kerja, yang mempunyai unsur pekerjaan, upah, dan perintah. ${ }^{14}$ Hubungan industrial adalah suatu sistem hubungan yang terbentuk antara para pelaku dalam proses produksi barang dan/atau jasa yang terdiri dari unsur pengusaha, pekerja/buruh, dan pemerintah yang didasarkan pada nilai-nilai Pancasila dan Undang-Undang Dasar Republik Indonesia Tahun 1945. Tujuan dari hubungan industrial adalah untuk mewujudkan hubungan kerja dan hubungan industrial yang harmonis, kondusif, dan berkeadilan di perusahaan. Ada tiga unsur yang mendukung tercapainya tujuan hubungan industrial, yaitu hak dan kewajiban terjamin dan dilaksanakan, bila terjadi perselisihan, dapat diselesaikan secara internal/bipartit, dan mogok kerja oleh pekerja serta penutupan (lock out) oleh pengusaha.

Sebagai implementasi undang-undang yang berkaitan dengan ketenagakerjaan, beberapa pemerintah provinsi maupun pemeritah Kabupaten/Kota telah membentuk peraturan daerah. Upaya ini dilakukan oleh pemerintah daerah sebagai langkah menstabilkan dan menjaga keharmonisan hubungan industrial di wilayah masing-masing.

${ }^{13}$ Wirjono Prodjodikoro, Asas-Asas Hukum Perdata, (Bandung : Penerbit Sumur Bandung, 1983), hlm. 20.

${ }^{14}$ Lihat Pasal 1 Angka 15 Undang-Undang Nomor 13 Tahun 2003 tentang Ketenagakerjaan 
Setiap daerah menghadapi kendala dan perselisihan hubungan industrial yang berbedabeda, maka tiap daerah memiliki regulasi yang berbeda pula untuk melakukan penyelesaian. Tenaga kerja merupakan hal kompleks yang dapat mempengaruhi berbagai aspek dalam suatu negara. Karena berkaitan dengan hak yang dimiliki pekerja sebagai warga negara dan para pekerja memiliki Hak Asasi Manusia (HAM) yang harus dipenuhi. Dalam UUD Tahun 1945 secara umum mengatur mengenai HAM secara mendasar. Pada pasal 27 ayat 1 dijelaskan bahwa "Segala warga negara bersamaan kedudukannya di dalam hukum dan pemerintahan dan wajib menjunjung hukum dan pemerintahan itu dengan tidak ada pengecualian. Hal tersebut semakin diperkuat pada pasal 28D ayat 1 yang menyebutkan "Setiap orang berhak atas pengakuan, jaminan, perlindungan, dan kepastian, dan kepastian hukum yang adil serta perlakuan yang sama di hadapan hukum".

Sementara pada pasal 27 ayat (2) Undang-Undang Dasar Negara Republik Indonesia Tahun 1945 menyatakan bahwa "tiap-tiap warga negara berhak atas pekerjaan dan penghidupan yang layak bagi kemanusiaan" Artinya negara berkewajiban untuk menyediakan pekerjaan atau lapangan kerja bagi seluruh warga negara agar memperoleh penghidupan yang layak dan mencapai kesejahteraan. Pasal 28D ayat (2) menyatakan bahwa "setiap orang berhak untuk bekerja serta mendapat imbalan dan perlakuan yang adil dan layak dalam hubungan kerja."

\section{Kewenangan Pemerintah Daerah dalam Mengatur Larangan Penahanan atau Penyimpanan Dokumen Asli Pekerja oleh Pengusaha pada Peraturan Daerah Provinsi Jawa Timur Nomor 8 Tahun 2016 tentang Penyelenggaraan Ketengakerjaan}

Asas legalitas merupakan dasar pada setiap penyelenggaraan kenegaraan dan pemerintahan atau dengan kata lain, setiap penyelenggaraan kenegaraan dan pemerintahan harus memiliki legitimasi yaitu kewenangan yang diberikan oleh undang-undang. Dengan demikian, substansi asas legalitas adalah wewenang, yaitu kemampuan untuk melakukan tindakan-tindakan hukum tertentu. Menurut H.D. Stout wewenang adalah pengertian yang berasal dari hukum organisasi pemerintahan yang dapat dijelaskan sebagai keseluruhan aturan-aturan yang berkenaan dengan perolehan dan penggunaan wewenang-wewenang pemerintahan oleh subjek hukum publik di dalam hubungan hukum publik. Menurut F.P.C.L. Tonnaer, kewenangan pemerintah dalam kaitan ini dianggap sebagai kemampuan untuk melaksanakan hukum positif dan dengan begitu dapat diciptakan hubungan hukum antara pemerintah dengan warga negara. ${ }^{15}$

Salah satu unsur penting di dalam hubungan pusat dan daerah adalah pembagian kewenangan.Secara umum kewenangan pemerintahan dapat diperoleh melalui atribusi, delegasi dan mandat serta tugas pembantuan (medebewind). ${ }^{16}$ Pemerintahan daerah menyelenggarakan urusan pemerintahan menurut asas otonomi dan tugas pembantuan

\footnotetext{
${ }^{15}$ Ridwan HR, Hukum Administrasi Negara. (Jakarta: PT Raja Grafindo Persada,2013).hlm. 70-71.

${ }^{16}$ Nurmayani, Hukum Administrasi Daerah, (Bandar Lampung: Fakultas Hukum Unila,2016), hlm. 24
} 
dengan prinsip otonomi seluas-luanya. Urusan yang menjadi kewenagan Pemerintah Pusat diatur dalam Pasal 6 ayat (1) dan (2) Peraturan Pemerintah Nomor 36 Tahun 2007 tentang Pembagian Urusan Pemerintahan antara Pemerintah, Pemerintah Provinsi, Pemerintah Kabupaten/Kota. Klasifikasi urusan pemerintahan secara khusus diatur dalam Pasal 9 Undang-Undang Nomor 23 Tahun 2014 tentang Pemerintahan Daerah yang meliputi urusan pemerintahan absolut, urusan pemerintahan konkuren dan urusan pemerintahan umum.

Berdasarkan pembagian kewenangan yang oleh undang-undang diatur sebagai urusan pemerintahan dalam UU No. 23 Tahun 2014 tentang Pemerintahan Daerah, terbentuknya Peraturan Daerah Provinsi Jawa Timur No. 8 Tahun 2016 tentang Penyelenggaraan Ketenagakerjaan merupakan urusan konkuren wajib non pelayanan dasar Pemerintah Daerah Provinsi di bidang tenaga kerja sebab pemerintah daerah berhak menetapkan kebijakan daerah untuk menyelenggarakan urusan pemerintahan yang menjadi kewenangan daerah. Tenaga kerja adalah setiap orang yang mampu melakukan pekerjaan guna menghasilkan barang dan/atau jasa baik untuk memenuhi kebutuhan sendiri maupun untuk masyarakat. ${ }^{17}$

Pembentukan peraturan daerah Provinsi merupakan upaya pemerintah daerah untuk mengatur dan mengatasi kondisi khusus yang dihadapi di wilayah tersebut. Dalam bidang ketenagakerjaan, disebutkan bahwa Pemerintah Provinsi berwenang dalam :

a. Penetapan kebijakan hubungan industrial, perlindungan pekerja dan jaminan sosial pekerja.

b. Penetapan standar keselamatan kerja, kesehatan kerja, higiene perusahaan, lingkungan kerja dan ergonomi.

c. Penetapan pedoman penentuan kebutuhan fisik minimum.

Terbentuknya Peraturan Daerah Provinsi Jawa Timur No. 8 Tahun 2016 tentang Penyelenggaraan Ketenagakerjaan merupakan kewenangan pemerintah daerah berdasarkan kewenangan atribusi untuk mengatur dan mengelola urusan pemerintahan tertentu sebagai urusan rumah tangganya yang telah diatur dalam Undang-Undang Pemerintahan Daerah dan Pasal 18 UUD Tahun 1945. Perihal pengaturan mengenai larangan menahan atau menyimpan dokumen asli pekerja oleh pengusaha sebagaimana yang dicantumkan dalam Pasal 42 Peraturan Daerah Provinsi Jawa Timur No. 8 Tahun 2016 tentang Penyelenggaraan Ketenagakerjaan merupakan kewenangan pemerintah daerah untuk membuat aturan berdasarkan kondisi khusus daerahnya. Walaupun dalam Undang-Undang No. 13 Tahun 2003 tentang Ketengakerjaan tidak mengatur secara jelas akan larangan atau anjuran penahanan atau penyimpanan dokumen asli pekerja, pemerintah daerah berhak untuk mengatur hal tersebut dalam upaya melindungi tenaga kerja di wilayah Jawa Timur karena masih dalam lingkup tugas dan kriteria kewenangan pemerintah daerah, sebagaimana amanat UU No. 23 Tahun 2014 dalam lampiran

\footnotetext{
${ }^{17}$ Pasal 1 ayat 2 UU No 13 Tahun 2003 tentang Ketenagakerjaan
} 
pembagian urusan bidang tenaga kerja bagian hubungan industrial dimana pemerintah daerah dapat melakukan suatu upaya pencegahan dan penyelesaian perselisihan hubungan industrial, mogok kerja dan penutupan perusahaan yang berakibat/berdampak pada kepentingan di 1 (satu) Daerah provinsi. Dalam hal ini hubungan industrial bertujuan untuk mewujudkan hubungan kerja dan hubungan industrial yang harmonis, kondusif, dan berkeadilan di perusahaan.

\section{E. PENUTUP}

Ratio legis pembentukan pengaturan larangan penahanan atau penyimpanan dokumen asli pekerja oleh pengusaha pada Pasal 42 Peraturan Daerah Provinsi Jawa Timur No. 8 Tahun 2016 tentang Penyelenggaraan Ketenagakerjaan dapat dilihat dari naskah akademik yang memuat penyusunan ataupun perancangan peraturannya. Mengenai larangan penahanan atau penyimpanan dokumen asli pekerja oleh pengusaha tidak dijelaskan secara jelas mengapa ada aturan tersebut. Namun dapat disimpulkan dari analisis permasalahan ketenagakerjaan yang terjadi sehingga aturan itu dibentuk bertujuan untuk memberikan penguatan dan perlindungan terhadap tenaga kerja agar terhindar dari perbuatan yang dapat merugikan dan tindakan sewenang-wenang dari pengusaha. Pemerintah daerah merasa perlu untuk membentuk suatu regulasi tentang perjanjian kerja yang jelas, transparan dan bersifat win-win solution.

Pemerintah seyogyanya melakukan upaya preferensi yaitu melakukan perubahan, perbaikan, sinkronisasi kembali Undang-Undang yang berkaitan dengan ketenagakerjaan pada umumnya dan yang berkaitan dengan hubungan kerja pada khususnya supaya larangan penahanan atau penyimpanan dokumen asli pekerja oleh pengusaha diatur dalam peraturan perundang-undangan yang lebih tinggi kedudukannya dari Peraturan Daerah Provinsi Jawa Timur No. 8 Tahun 2016 tentang Penyelenggaraan Ketenagakerjaan. Sebab peraturan daerah provinsi hanya dapat mengikat pada daerah otonom saja, sedangkan secara nasional tidak ada aturan yang mengatur secara jelas akan anjuran atau larangan penahanan dokumen asli pekerja oleh pengusaha. Hal tersebut bertujuan agar tercapainya suatu kepastian hukum secara nasional dan tidak ada suatu tindakan yang dapat merugikan pekerja.

\section{DAFTAR PUSTAKA}

Jazim Hamidi, Optik Hukum Peraturan Daerah Bermasalah, Prestasi Pustaka Publisher, Malang: 2011.

Johny Ibrahim. Teori dan Metodologi Penelitian Hukum Normatif, Bayumedia, Malang: 2011.

Ni'matul huda, Pengawasan Pusat terhadap Daerah dalam Penyelenggaraan Daerah, FH UII Press, Yogyakarta: 2007. 
Nurmayani, Hukum Administrasi Daerah, Fakultas Hukum Unila,2 Bandar Lampung: 2016.

Peraturan Daerah Provinsi Jawa Timur Nomor 8 Tahun 2016 tentang Penyelenggaraan Ketenagakerjaan

Ridwan HR. Hukum Administrasi Negara. PT Raja Grafindo Persada, Jakarta: 2013.

Satjipto Raharjo, Ilmu Hukum, PT. Citra Aditya Bakti, Bandung: 2005.

Soerjono Soekanto dan Sri Mamudji, Penelitian Hukum Normatif suatu Tinjauan Singkat, Rajawali Press, Jakarta: 1990.

Suharnoko, Hukum Perjanjian Teori Dan Analisis Kasus. Kencana, Jakarta: 2004

Undang-Undang Republik Indonesia Nomor 13 Tahun 2003 tentang Ketenagakerjaan (Lembar Negara Republik Indonesia Nomor 13 Tahun 2003

Undang-Undang Republik Indonesia Nomor 12 Tahun 2011 tentang Pembentukan Peraturan Perundang-undangan

Undang-Undang Nomor 23 Tahun 2014 tentang Pemerintahan Daerah Sebagaimana diubah dengan Undang-Undang Nomor 9 Tahun 2015

Wirjono Prodjodikoro, Asas-Asas Hukum Perdata, Penerbit Sumur Bandung, Bandung: 1983. 